\title{
Transfer Of Soft Technology Via FDI: Case Studies Of Us And Japanese Firms In India
}

\author{
Umakrishnan Kollamparambil, University of Witwatersrand, Johannesburg, South Africa
}

\begin{abstract}
This paper looks into the transferability of management technologies and spillovers through backward linkages through the medium of FDI to the host developing countries. The results of the case studies conducted in the Indian context reveal that significant inter-source country differences exist in the transfer of production organisation and human resource related technology to FDI firms. The benefits that the host country derives from technology transfer through FDI, depend to a large extend on the behavioral pattern of FDI which varies across source-countries
\end{abstract}

Keywords: technology transfer, management technology, foreign direct investment

\section{INTRODUCTION}

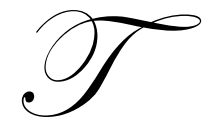

he central reason for seeking FDI in developing countries is that it is an important source of non-debt creating flows and a means for securing state of the art technology from firms in the developed countries. Chen (1996), in his exhaustive survey of literature on MNCs as agents of technology transfer points out the gaps in the transfer of organisational and managerial technologies. This paper therefore examines the transfer of soft technologies through the mode of FDI to host developing countries. Managerial and organisational technology depend to a great extend on the social and cultural milieu of its country. Therefore inter source behavioural differences may be expected in the nature of soft technologies and hence, a comparison of the nature of soft technologies between FDI sources is of relevance in this context. Given this backdrop from literature, this paper presents the insights gained through comparative case studies of US and Japanese firms in India.

\section{DOES SOURCE OF FDI MATTER?}

Studies on US, European and Japanese FDI, who together account for three-fourths of total global FDI outflows, in different host country contexts offer a comparison of the nature and behavior of various sourcecountries of FDI. Although bulk of literature tend to consider FDI as a homogenous entity some studies do bring out the behavioural differences between various sources of FDI.

In his investigation of Swedish industry, Samuelson (1977) identified US FDI as intensive in technical skills and capital (implying a bias towards producer industries) and European FDI as associated with advertising intensity (implying a bias towards consumer industries). Orr (1973) found in his study of foreign market shares in Canada that US penetration was distinguished by its research intensity alone as compared to non-US sourcecountries. Clegg (1987) comes to a similar conclusion in a comparative study of US, UK, Sweden and Japan noting that Japan has the least research intensity. A more recent study by Mody and Srinivasan (1998) have brought out the differences in the determinants of US and Japanese FDI flows. Kumar (2002) has not only brought out differences in the determinants, but also the differential behaviour of US and Japanese FDI in other aspects like export orientation, level of localisation and globalisation of R\&D.

Erramilli (1996) has argued that the national origin of an MNC affects its subsidiary ownership strategies. MNCs based in countries, where the dominant cultural traits are high power distance and low uncertainty avoidance, may prefer full ownership of their foreign affiliates. Japanese FDI has been found more willing to go in for joint ventures as against the strong preference of US and European FDI for majority or wholly owned investment. In a 
study of differences in the conflict between European, US and Japanese multinationals with the host countries, it was found that American MNCs have more interface conflicts with the host government compared to their Japanese counterparts who are plagued with operational problems (Negandhi and Baliga, 1979).

The role of trading houses (keiretsu) of Japan in promoting investments by small and medium sized firms as against the dominance of large multinationals from the West has been brought out in literature (UNCTAD, 1993). On the basis of an empirical investigation of US and Japanese investments in Taiwan, Korea, Singapore and Hong Kong, Yoshihara (1978) recorded source-wise differences in the characteristics. He found that US investment was concentrated in technology-intensive industry, whereas Japanese investment was in the light technology areas. Vertical linkage between Japanese parent companies and affiliates were found strong entailing poor backward spillover effect on host economy. In contrast, US investments were found stand-alone in nature with greater vertical linkages within the host country. Differences in the capital structure of affiliates, with equity investment accounting for a larger part of total Japanese investments vis-a-vis their US counterparts, has been noted. Further, Japanese investment per project appeared smaller than American investment. This has been explained by either the small size of the Japanese investing firm or the joint venture nature of entry. Lan (1996) however, characterizes Japanese investment to be relatively large sized wholly owned subsidiaries with strong export orientation compared to FDI from Hong Kong, Macau and Taiwan and Western sources in China.

Morgan (2001) points out that Japanese multinational firms are considered in general to be less diversified unlike the US conglomerates, concentrating on a particular range of skills and competencies around specific technologies and markets. There exists a tight integration between the technological competence based in Japan and their subsidiaries. On the other hand, subsidiaries and units within US and British multinational system are less tightly integrated and likely to be assessed in terms of their own specific financial performance rather than in terms of their overall strategic contribution.

Earliest theoretical works are by Kojima (1978) and Ozawa (1979), who have differentiated the trade and technology impact of US and Japanese FDI on the basis of their concentration ratios in various industry groups. They argue that the Japanese-type FDI is trade-enhancing but the American-type FDI is trade-substituting in nature. Subsequently, empirical investigations undertaken in various country contexts have investigated the trade orientation of US and Japanese FDI.

A more recent study by Encarnation (1999) has compared the operational characteristics of US and Japanese multinationals identifying and explaining the emerging differences and similarities between the two source-countries. He has disputed the stance that Japanese investment is more trade enhancing arguing that Japanese multinationals have been less reliant on international trade to generate their foreign subsidiaries sales in Asia than have American multinationals. He has also brought out that Japanese investments continue to source their inputs from back home rather than through local or other third country suppliers and they more aggressively control this two way trade of outputs and inputs through intra-company shipments linking multinational parents and their subsidiaries. This substantiates the conclusion of Institute of Developing Economies (1994) that US affiliates in Malaysia rely more on local supplies than do firms either from Japan nor the European Union.

Trade behaviour differences is more studied in various host country contexts than the differences in technology transfer behaviour between the two source-countries. Kumar (1997) has emphasised that FDI does not automatically involve the same level of technology transfer and pointed the inadequacy in equating FDI to technology transfers. Literature has hinted at US multinationals being considerably more open-handed, unrestricted and generous in transferring technology than have their European and Japanese counterparts (Cavusgil, 1985). Isolated studies that have compared different source-countries of FDI in different country context have pointed to the slowness and hesitation of Japanese in transferring technology (Urata, 1995) and, non-transferability of the Japanese management techniques (Sedgewick, 1995). Other studies point to the limited linkage effects of Japanese production in host countries due to their preferences for sourcing inputs from their suppliers in Japan (Borrus, 1999) ${ }^{1}$ and non-globalisation of Japanese R\&D (Ravenhill, 1999) etc. Siddharthan (1998) has compared the conduct and performance variables of Japanese and European affiliates in India and has brought out their behavioural differences especially in their external orientation. He found the Japanese to be importing more machinery and materials than 
their European counterparts, while European affiliates were found to be importing more components than the Japanese.

There is sufficient evidence in various country contexts pointing to differences between various sources of FDI. However, an FDI source-country may be expected to behave differently in different country context. We therefore undertake a study of behaviour of US and Japanese FDI in a single host country context, viz., India. The purpose of this study is to develop an understanding of the behaviour of US and Japanese FDI based on their general characteristics in the Indian context.

\section{COMPARISON OF US AND JAPANESE FDI IN INDIA}

The increasing significance of FDI in India in recent years is evident from the jump in the ratio of FDI to gross fixed capital formation from 0.3 percent in 1992 to 3.6 percent in $1995^{2}$. The increase in FDI inflows in recent years has not been on the same patterns as in the past. The United Kingdom undertook the bulk of the foreign investments in pre-independent India. This was only natural considering that they wielded the political power and therefore could receive maximum incentives and operate under conducive policies in India. After independence, UK continued to have a major share of outstanding FDI for many years. However share of UK has steadily decreased while that of the US has increased to overtake the share of UK. Other countries especially Germany and Japan have substantially increased their stronghold.

Table 1: County-wise FDI inflows to India during the 1990s (percentage shares)

\begin{tabular}{|l|c|c|c|c|c|c|c|c|c|}
\hline \multicolumn{1}{|c|}{ Year } & USA & Japan & Mauritius & Germany & Italy & Holland & $\begin{array}{c}\text { South } \\
\text { Korea }\end{array}$ & Others & $\begin{array}{c}\text { USA\& } \\
\text { Japan }\end{array}$ \\
\hline $1992-93$ & 7.9 & 9.3 & - & 7.5 & - & 7.5 & - & 67.9 & 17.2 \\
$1993-94$ & 24.6 & 9.2 & - & 8.7 & - & 11.7 & - & 45.9 & 33.8 \\
$1994-95$ & 23.1 & 10.8 & 22.5 & 4.0 & - & 5.1 & 1.4 & 33.1 & 33.9 \\
$1995-96$ & 13.8 & 4.3 & 35.8 & 7.1 & - & 3.5 & 1.7 & 33.9 & 18.1 \\
$1996-67$ & 11.8 & 4.7 & 41.1 & 8.1 & - & 6.0 & 0.3 & 28.0 & 16.5 \\
$1997-98$ & 23.2 & 5.5 & 30.4 & 5.1 & 1.5 & 5.4 & 11.3 & 17.6 & 28.7 \\
$1998-99$ & 22.7 & 11.8 & 29.5 & 5.7 & 5.8 & 2.7 & 4.3 & 17.7 & 34.5 \\
$1999-2000$ & 22.5 & 9.0 & 31.7 & 2.0 & 7.9 & 5.2 & 0.5 & 21.3 & 31.5 \\
$2000-2001$ & 16.8 & 8.2 & 44.1 & 5.9 & 1.5 & 4.0 & 1.3 & 18.3 & 25.0 \\
$2001-2002$ P & 12.2 & 4.3 & 62.3 & 2.5 & 0.9 & 2.3 & 0.1 & 14.9 & 16.5 \\
\hline Average 1992-93 & 17.86 & 7.71 & 29.74 & 5.66 & 1.76 & 5.34 & 2.09 & 29.86 & 25.57 \\
to 2001-2002 & & & & & & & & & \\
\hline
\end{tabular}

Source: Reserve Bank of India, Annual Reports, various issues.

Note: 'P' stands for provisional estimates.

The most striking phenomenon of recent FDI inflow to India is that Mauritius, which is considered as a tax haven, has emerged as the single largest source since the mid-90s (Table 1). Although it is not possible to state clearly the original source-country of FDI channeled through Mauritius, patterns indicate that recent fall in US and Japanese FDI may be accounted for partly by flows channeled through Mauritius ${ }^{3}$. FDI sourced from Mauritius is directed to service and finance sectors and rarely to the manufacturing sector. Thus keeping apart flows from Mauritius, the share of US and Japanese FDI continue to be the two largest sources of FDI even though their share has been falling in total FDI in recent years. The nature of FDI from these two sources is now taken up for discussion in greater detail.

The period January 1991 to October 1999 saw 1456 cases of US FDI accounting for an inflow of Rs. 9530.6 crores. This is 19 percent of the total number of cases and 20 percent of the total FDI inflows into India during the period. On the other hand, the same period saw 459 Japanese cases of investment totalling to Rs.2989 crores. This is 5.6 percent of total number of cases and 7 percent of total FDI inflows into India. 
US FDI is found to be less concentrated in a few industries unlike Japan. Substantial investments are found in such diverse industries like food, textiles, chemical, and transportation industries (Table 2). The highest share of investments went into transportation (12 per cent), followed by commercial banks ( 9 per cent), computer software industry (10.4 per cent) and chemical (8 per cent).

The industrial distribution of Japanese FDI on the other hand, can be seen to be highly concentrated in three industries: transportation (21.5 per cent), petroleum products (19.6 per cent) and electrical and electronics (16.26). These three together account for more than half the total inflows (Table 3). Other prominent industries invested in are chemicals, telecommunications and building materials.

Table 2: US FDI in India: Industry-wise 1991-1999

\begin{tabular}{|l|c|c|c|}
\hline \multicolumn{1}{|c|}{ Industry } & Amount (Rs. crores) & Relative share (\%) & No. of cases \\
\hline Industrial farm Equipment & 137.7 & 1.45 & 58 \\
Engineering \& Construction & 138.2 & 1.45 & 77 \\
Pharmaceuticals & 139.2 & 1.46 & 22 \\
Glass \& Building Material & 151.5 & 1.59 & 25 \\
Textiles & 177.4 & 1.86 & 42 \\
Telecommunication & 286.0 & 3 & 59 \\
Food & 393.6 & 4.13 & 117 \\
Electronics \&Electrical & 416.5 & 4.37 & 56 \\
Auto ancillaries & 500.7 & 5.25 & 15 \\
Automobiles & 647.5 & 6.79 & 107 \\
Chemicals & 728.4 & 7.64 & 70 \\
Banks & 856.2 & 8.98 & 291 \\
Computer Software & 995.9 & 10.45 & 509 \\
Others & 3961.7 & 41.56 & 1456 \\
Total & & & 100 \\
\hline
\end{tabular}

Source: Estimates based on information collected from Reserve Bank of India.

Table 3: Japanese FDI in India: Industry-wise 1991-1999

\begin{tabular}{|l|c|c|c|}
\hline \multicolumn{1}{|c|}{ Industry } & Amount (Rs. crores) & Relative share (\%) & No. of cases \\
\hline Electrical & 102.8 & 3.44 & 21 \\
Diversified financials & 130.1 & 4.35 & 15 \\
Glass \& Building material & 159.0 & 5.32 & 14 \\
Telecommunications & 160.7 & 5.38 & 38 \\
Chemicals & 216.4 & 7.24 & 14 \\
Automobiles & 300.6 & 10.06 & 57 \\
Auto ancillaries & 342.4 & 11.45 & 45 \\
Electronics & 383.1 & 12.82 & 10 \\
Petroleum refining & 587.0 & 19.64 & 232 \\
Others & 607.0 & 19.09 & \\
Total & & & 100 \\
\hline
\end{tabular}

Source: Estimates based on information collected from Reserve Bank of India. 
Based on the industrial distribution of US and Japanese FDI in India, we chose the auto ancillaries sector to conduct our case studies to enable a comparative look at the transfer of production organisation and human resource related technology to FDI firms.

\section{US AND JAPANESE MANAGEMENT TECHNOLOGIES}

US production technology until the 70s focused on the mass production using standardised technologies aiming at cost reduction through scale economies rather than product competition. Fordian concept of large-scale assembling and strict division of labour was considered the answer to survival through cost reduction. However, with the life span of technology and product being cut short through rapid changes and the concept of homogeneity becoming obsolete, and product differentiation and personalised products coming to rule the market, the American paradigm of mass production ran into difficulties. This led to a shift from price competition to product competition. The Japanese success in competing with the US has been regarded greatly due to the constant technological dynamism and changing production to keep pace with the former. Japanese production model first exhibited that it is possible to draw strength from the human related dimension of engineering technologies, workplace practices and corporate culture. The philosophy of techniques like just-in -time delivery (in the place of the usual just-in-case delivery) is to produce to order rather than to stock up. This results in constant restructuring of production layout, absence of job specifications as well as horizontal mobility of workers and job rotation. This necessitates the downsizing of production and multi-skilled workforce in keeping with the nature of order. Also, the absence of inventories and nature of demand-driven system requires total quality control (TQC) and quality circles (QC) to ensure zero defects. The role of supplier networking and vendor development also gained relevance with the rise of "strategic management" in the 70s as a means of achieving sustainable competitive advantage for a firm to improve profits and performance.

\section{INSIGHTS FROM CASE STUDIES}

The insights gained through case studies of US and Japanese firms in India indicate that strict patterns in management differences between US and Japanese firms do not exist any more. The better results yielded through the Japanese management mode has lured the US firms to adopt the latter's systems to a great extend, imbibing within them the concepts that are possible given the differences in cultural milieu and social attitudes. We present the results in two parts. Initially we compare the soft technology utilised for organising production and human resource management within the affiliate and then move on to present our findings regarding vendor development and supplier management. The profiles of the four firms chosen for the case study are detailed in Table 4 .

Table 4: Profile at a glance

\begin{tabular}{|c|c|c|c|c|}
\hline & Cummins India Ltd & Ceekay Daikin & $\begin{array}{c}\text { Tata Johnson } \\
\text { Controls } \\
\end{array}$ & $\begin{array}{c}\text { Tata Yazaki } \\
\text { Autocomp }\end{array}$ \\
\hline Year of Incorporation & 1962 & 1973 & 1996 & 1996 \\
\hline Year of FDI entry & 1962 & 1984 & 1996 & 1996 \\
\hline Source Country of FDI & US & Japan & & Japan \\
\hline Name of foreign company & Cummins Inc & Exedy Corp. & Johnson Controls & Yazaki Corp. \\
\hline $\begin{array}{l}\text { Equity Stake of Foreign } \\
\text { partner }\end{array}$ & 51 & & 50 & \\
\hline No. of Employees & 2300 & 352 & 340 & 215 \\
\hline Product & Diesel engine & Clutch Discs & Seatings & Wiring harness \\
\hline Location & Pune & Aurangabad & Pune & Pune \\
\hline Clientele & $\begin{array}{l}\text { Power generation, } \\
\text { automotive } \\
25\end{array}$ & $\begin{array}{l}\text { Maruti , TELCO } \\
15\end{array}$ & $\begin{array}{l}\text { Fiat, Ford, Mercedes } \\
\text { Benz, Telco } \\
54\end{array}$ & TELCO \\
\hline Market Share (\%) & 833.55 & 55.8 & 63.2 & 60 \\
\hline Net Sales (Rs. Crores) & 0.9 & 21.9 & 0 & 50.3 \\
\hline Imports /sales (\%) & 34.6 & 0.3 & 0 & 0 \\
\hline $\begin{array}{l}\text { Exports/Sales (\%) } \\
\text { PAT/Assets (\%) }\end{array}$ & 17.2 & 2.95 & 0.23 & $\begin{array}{l}0 \\
0.38\end{array}$ \\
\hline
\end{tabular}




\section{Technology Transfer Behaviour: Comparative Experience}

Conventionally, the greatest lure of FDI to the host developing economies has been the argument that it is a conduit for the transfer of state of art technology ${ }^{1}$. There are important differences in the mode of transfer of technology such as licensing, outright purchase of equipment (hardware technology) or know-how or/and in the form of detailed specifications or blueprints (medium ware technology) or transfer through man to man interaction (software technology). The collaboration is expected to help the technology-receiving firm to add to its capabilities although the differences are difficult to resolve because of the inherent complexities of the determinants of the learning process and its relationship with technical building. Through our case studies we have looked specifically into the extent to which collaborations facilitated adaptation of technology and thereby assisted in building up technological capabilities. The parameters involved in unveiling this are difficult to examine empirically. However, certain processes in the capability building can be identified and we have used qualitative and quantitative aspects used by earlier researchers on foreign collaboration to identify the processes towards capability building. To illustrate some of these: the duration of collaboration, cost of technology, restrictive clauses embodied in agreement, the degree of autonomy and support given to affiliates in conducting R\&D, local adaptation of materials imported, training provided etc. may be of interest to us in establishing the process towards the capability building. It may be admitted here that comprehensive information on all these aspects were difficult to gather, for on many of these aspects firms were not divulging information, therefore our observations on the technology behaviour of these firms may be taken as a rule of thumb.

\section{Transfer Of Management Practices}

Production technology until the 70s focussed on the mass production using standardised technologies aiming at cost reduction through scale economies rather than product competition. This is despite the fact that around two-thirds of production in the engineering and wood-based industries exist in small batches, the dominant perception of manufacturing is one of large-batch production (Hoffman and Kaplinsky 1988). Fordian concept of large scale assembling and strict division of labour was considered the answer to survival through cost reduction. However, as observed earlier with the life span of technology and product being cut short through rapid changes and the concept of homogeneity becoming obsolete, and product differentiation and personalised products coming to rule the market, the American paradigm of mass production ran into difficulties. This led to a shift from price competition to product competition. The Japanese success in competing with the US has been regarded greatly due to the constant technological dynamism and changing production to keep pace with the former.

Mass production paradigm becomes inappropriate in this scenario as it requires a stable environment to ensure conditions under which massive investment in inflexible capital equipment can be utilized to break-even. The Japanese answer was to shift to "production on demand" rather than "off-the shelf" practice of US, through small batch production. Flexible specialisation was seen as the answer to this problem and with retrospect can be seen as a turning point in the history of mechanisation. Hoffman and Kaplinsky, in their book 'Driving force', terms the US mode of mass production as "machinofacture" and the Japanese as "Systemofacture".

With this changing production norms the thrust in production forces also changed from relegating labour process to the role of fettering production to emphasising their contribution in imbibing flexibility and changes in accordance with demand. Embodied technology in this paradigm is seen as largely malleable to alternative sets of production needs and labour plays a more creative and flexible role unlike the strict division of labour and fixed roles under mass production scheme. This flexibility in work pattern entails that the labourer be in command of a range of skills so that they can perform multi-tasking work and the deskilling of labour entailed in strict Fordian division of labour is reversed. This is not to undermine the importance of embodied technology and the role of electronics-based flexible automation technologies in bringing about a shift in production paradigm. But the Japanese management system is hailed in literature as making this possible through revolutionising the soft technology of management and organisation to bring out the best in labour performance of tasks on shop-floor.

\footnotetext{
${ }^{1}$ Nayyar (1983) has cited the case of Kirloskar Cummins to demonstrate the successful adaptation of sophisticated large-scale technology to an entirely different economic environment.
} 
Spillovers of this technology to the host country through Japanese FDI firms can be considered beneficial to the host economy as a whole.

Another emerging impact of this new system of production to demand has been the thrust given to inventory control. The large stock of inventory to keep the production line moving at all costs in the mass production system became outmoded in a demand driven system. Just-in-time (JIT) inventory management was introduced not only to reduce the inventory costs, but also make possible changes in inputs necessitated by a change in specification of output. This aspect of Japanese management has received a lot of attention in other countries and the need to hold inventory near-zero has come to be considered an important management objective.

Corollary to this, the zero-defect policy was introduced since there was no inventories to back up the system if anything wrong was noticed. Hence enhanced quality control measures as well as a complete reorganisation of the way in which components were delivered were necessitated to provide greater quality assurance. Quality control and defect detection came to become the concern of every worker and not just of the quality control division. This in turn led to giving a measure of control to the line-worker by entrusting with the responsibility of noticing and correcting any defect noticed at the assembly line itself. The active and creative role assigned to the worker in this set-up provided another important service. And that is of incremental technical change brought upon by the assembly line-workers. This is encouraged and furthered by a scheme for suggesting improvements, most of which are rewarded. The nature of labour processes in the shop floor extends beyond this and includes various other aspects. The founder of Sony Inc., Morita (1987) in his book "Made in Japan" puts it as a paternal relationship shown towards the labour by the firm to give them a feeling of oneness and have a set of horizontal rather than hierarchical relationship. This is encouraged through a common dress-code across ranks, common cafeteria, bringing down partitions in the office, lifetime employment etc.

This is in direct contrast to the American mode of management where to hire and fire was the prerogative of the management which they did not hesitate to exercise. These contrasting styles of production and related aspects are considered the soft technology aspects which may be practised in the Japanese and US FDI firms giving the domestic firms a chance to understand and adapt the same.

However, the transferability of Japanese soft technology to different locales of production is itself an open question as the labour process reflects one aspect of social relations that is a result of long history of acculturation. This affects the attitudes to work and to their superiors and subordinates. So if this wider level of acculturation is at odds with the attitudes being demanded in the work-place it is doubtful whether the labour -process adopted by the management can succeed. The immobility of the highly acclaimed Japanese Management Technique (JMT) outside Japan through Japanese firms have been brought out in various other studies in different country contexts (Urata 1995). Sedgewick (1995) too has concluded from his study of FDI in Thailand that the social milieu of multinationals or the ownership of MNCs matter to the organisation of production and quality of managerial technology transfers. He has noted that Western MNCs are more successful in providing managerial technology transfers to local employees in Asia than are Japanese MNCs due to centralisation of decision making in Japanese affiliates.

Given this backdrop from literature, the insights gained through case studies of US and Japanese firms in India indicate that such strict patterns in management differences between US and Japanese firms do not exist any more. The better results yielded through the Japanese management mode has invited the US firms to adopt the latter's systems to a great extend, imbibing within them the concepts that are possible given the differences in cultural milieu and social attitudes.

CIL production is a classic example of the point wherein small batch production on demand is undertaken. With over 22 models of diesel engines with further customer requirement changes in specific cases being undertaken on a mixed product-line, considerable flexibility of production exists. Computerized Numeric Control (CNC) is installed to enhance the flexibility and reduce the switchover time to suit small batch production. Computerisation process was started since the late eighties and early 90 s at CIL. 
Horizontal job rotation across the assembly-line at CIL assures that workers are not deskilled by performing just one function. Great emphasis is given to labour training with extensive training programmes being conducted to make the worker capable of handling the different job requirements. Apart from technical training on QS 9000, PRO engineering, safety, cost reduction, problem solving, zero-defects etc.; behavioural training is also offered on moral re-armament, working in teams and group behaviour. Training on corporate aspects such as Cummins code of conduct, information security management diversity and treatment of others are also offered to 98 per cent of CIL employees. A special training team exists in the company who offer training both inside the company premises with space allocated specifically for the purpose as well as outside. Occasionally outside expertise are invited to handle classes.

The CIL Human Resources Mission statement states "Every human being has a potential, our mission is to develop and lead employees for managing change by avoiding conflicts for the growth of the organisation, as well as the individual". The success in implementation of the same is reflected in the fact that CIL has not seen a man day lost due to labour militancy since inception. On the contrary, CIL seems to benefit from encouraging creative suggestions and contributions from the workers on assembly line on possible improvements in technology or process. The suggestion scheme was implemented over 15 years back. Every suggestion is taken seriously and discussed at the monthly meeting of the Suggestion Committee. The worker whose suggestion is implemented is rewarded on the basis of nature of the suggestion. On an average three to four such suggestions are found worthy of implementation by the Committee. This incremental innovation is truly a continuos process spearheaded by the workers at CIL.

However, the movement along the personnel ladder is more the result of performance rather than loyalty and experience as cited in the Japanese management literature. Other deviations from Japanese mode are seen in the absorption of workers/managers experienced from other firms. This is a typical US behaviour considered unethical and "stealing" by the Japanese. However, a large number of fresh candidates from educational institutions are given apprenticeship, and the company retains about 50 percent of them. Similarly labour turnover, considered an act of betrayal by the Japanese is considered very normal in the US system and in fact is considered an important source of enhancing spillovers to the host economy (UNCTAD 2001). The attrition or turnover rate of managers at CIL was seen higher at 7.7 percent compared to other similar firms in the same city (Table 5).

Table 5: Attrition rate of selected firms in Pune 1999 (per cent)

\begin{tabular}{|l|c|}
\hline \multicolumn{1}{|c|}{ Company } & Attrition rate \\
\hline Telco & 5.5 \\
Bajaj Auto & 4.5 \\
Bharat Forge & 2.5 \\
KOEL & 16 \\
Phillips & 6.5 \\
CIL & 7.7 \\
\hline
\end{tabular}

The JIT inventory management can also be seen to have been adopted at CIL to suit small batch production. This is enforced with much seriousness with the parent company giving strict instructions to follow minimum inventory policy in order to reduce wastage accruing from changing technology, held up finance and different product orders. Serious efforts are underway to introduce the concept of JIT throughout the value chain and for this purpose an internet based Supply Chain Management (SCM) has been launched through which the suppliers are updated on the daily changes in the requirements of CIL. As a result CIL has succeeded in bringing down its inventory holding from 25 per cent to 18 per cent (Table 6). Zero-defect policy is followed strictly as the minimum inventory does not provide much back-up to meet demands in the event of defective products. Quality circles and checking for defects at every stage of assembly line of every product is undertaken. The worker is empowered to stop production line and remove the product on noticing a defect. The suppliers of components are also required by CIL to implement zero-defect production system. This aspect is taken up for more detailed discussion in the section on linkages. 
Table 6: Just-in-time performance

\begin{tabular}{|l|c|c|c|c|}
\hline & \multicolumn{2}{|c|}{ Ceekay Daikin } & \multicolumn{2}{c|}{ CIL } \\
\cline { 2 - 5 } & 1990 & 1998 & 1990 & 1998 \\
\hline Inventory/Sales (\%) & 42 & 41 & 25 & 18 \\
Average days raw materials (no. of days) & 128 & 123 & 89 & 80 \\
Average days finished goods (no. of days) & 4.5 & 6.2 & 0.43 & 0.31 \\
\hline
\end{tabular}

Ceekay Daikin, on the other hand, being Japanese firm shows its practice of the much-hailed Japanese mode of production management leaves much to be desired. The Japanese management practice of JIT to save storage costs is less effectively practised at Ceekay. This is reflected in the higher costs incurred on account of storage as is indicated by the higher average days of holding of raw material and finished goods (Table 6). Although 80 per cent of its production utilises small batch technology and flexibility in labour ability is automatically made necessary, labour training and related activities leaves much to be desired. No formal training is offered and a new entrant is taught on a one-to-one basis on the shop floor. The skill imparted is strictly job specific and there is no job-rotation or horizontal movement among workers. Under the circumstances it is not surprising that as yet no suggestion from the worker on process improvement has been found worthy to accept. The suggestion box was introduced less than a year back and moreover the criterion of incentives is yet to be decided. This raises the question of transferability of the management system in a social milieu different from Japan. Although Ceekay has a commendable record of labour relations, it was recently marred by a strike by the laborers in protest against the company decision to enforce one day of lay-off each week.

Thus although the management of Ceekay claimed to be introducing the concepts of JIT and zero defects it was not found to be very effective. As shown in table 6 CIL has greater efficiency in this regard with lower average days of inventory, and inventory to sales figures compared to Ceekay. The Japanese are also seen as reluctant to introduce the labour related aspect of JMT in India, possibly due to the differing cultural and social set up of the host country. The turnover rate is minimal across all categories of employees reducing the spillover generation through this medium. This is in keeping with the findings of Yamashita (1999) that Japanese affiliates in Indonesia resorted to robotisation and mechanisation by which minimum training and skill is passed on to the local employees as part of "on the job training". This ensures minimisation of job-hopping by local employees after imbibing the know-how as a result of which technology dissemination is effectively restricted. At the managerial levels, candidates with experience are preferred at Ceekay. Hence there is a reversal of spillovers taking place through this medium with Ceekay gaining from the experience the managers gained elsewhere.

TJC is yet another example of a US affiliate efficiently adopting the JMT. TJC has a partly dedicated and partly mixed product line. Hence both the fordian concept of mass specialisation as well as Japanese flexibility in production is incorporated under the same roof at TJC in keeping with stage and model of production. For example, seating systems for models such as Tata Sumo, Mercedes Benz, Tata Safari, Tata Indica etc. have separate assembly line. However, certain stages of production like sewing and cutting of seat covers and linings are undertaken for different models on a mixed product line with the help of $\mathrm{CNC}$ tools to ensure flexibility.

Special efforts are taken at TJC to impart training of technical, non-technical and functional nature to all employees. Even non-technical employees are given training on the assembling activities and the Human Resource manager interviewed proudly reported that he had actually manually assembled seats himself though it was in no way related to his responsibilities at TJC. Similarly the shop-floor workers are trained in all the steps involved in production which not only enables horizontal rotation of workers by imbibing in the workers multiple skill but more importantly it gives them a sense of purpose in their role in the production line. Apart from this, workers involvement and participation is promoted at TJC at every level through constituting various committees for welfare, recreation and extending to them the power of decision making. At the production scene, the suggestions committee is convened every month to deliberate on the suggestions provided by the shop-floor personnel. Forty such suggestions have been implemented resulting in enormous savings in cost as well as improvement in quality. Spot rewards in monetary form are given for implemented suggestions and they are further felicitated at Annual Day Functions. 
TJC being a highly open and horizontal organisation the industrial relations was found to be highly congenial. Common uniforms from top down and similar facilities (canteen and recreational facilities etc.) for every employee has to some extent contributed o workers' involvement and goodwill. Despite this, the management has to constantly worry about the high turnover rate at all levels of employment. Attrition of the technical workforce is attributed to the IT boom which enables them to entice the technically skilled personnel by the very attractive pay packages. Even the lowest rank worker at TJC being a science graduate, the turnover rate is high as they leave for pursuing further studies. A significant proportion of workforce being women, marriage also has been cited as reason for moving out of TJC. There is thus a high level of spillover occurring through labour turnover at TJC. Although TJC takes active interest in retaining their personnel by providing frequent promotions and other incentives, it can rarely compete on the financial packages offered by information technology sector. This is because TJC functions on a very thin margin because only 6 percent of output is the result of value addition within TJC. Outsourcing has been resorted to for metal frames, tracks and recliners to get the benefit of economies of scale and better inventory management. In this context the management of raw materials, intermediary and output inventory becomes crucial to prevent all sorts of wastes and hold up of finance and is in fact the main reason why JIT is taken up in earnest at TJC.

This in turn necessitates special efforts on vendor development. This aspect is taken up in detail the subsequent section on backward linkages, but it need be mentioned here that the suppliers are also convinced of the need for inculcating JIT and zero-defects philosophy and minimising costs as well as product per million (PPMs) with defects or delivery schedule rejection.

Production at TYA is of more or less homogenous nature with very little diversification. Hence the product-line is dedicated to it with little flexibility infused into the system. However, production is made to demand and to suit customer specification with the use of $\mathrm{CNC}$ tools which ensures flexibility in production. On the organisational front, the most striking aspect is the high proportion of expatriate employment at all levels: managerial, technical as well as in R\&D. Five of the fourteen managers, and one of the three R\&D personnel were found to be expatriates. This has been part of the joint venture agreement between Yazaki and TACO, with expatriates to be replaced after 4 years of TYA. However, the Yazaki representatives continue at TYA even at the end of this fixed tenure.

Other aspects of Japanese management viz., policy of zero-defects through quality circles and constant reviews to complement the policy of minimum inventory is observed at TYA. Geographical proximity of suppliers and providing one-monthly forecasts to suppliers is also ensured to maintain low inventory of raw materials and intermediaries. Flexibility in labour skills is imparted through providing wide-ranging technical training through the training cell at TYA to all workers. Outside faculties are invited to provide non-technical training also. Job rotation is undertaken every three months to ensure individual concentration and interest. Although there is no standing suggestion committee, three-monthly open-house discussions are carried out to get feed-back from workers and evaluate the suggestions. Incorporated suggestions are given nominal non-financial rewards. More importantly, it is cited in the personnel record of the employee and is taken into account in the yearly assessment for promotions. Although there is no written policy of lifetime employment, this is usually the norm at TYA.

Although we see a greater spirit of JMT at TYA than at Ceekay, both the US affiliates, CIL and TJC seem to have been more successful in imbibing the spirit of Japanese Management Techniques. The deliberate policy of Japanese firms not to instil multi-skill among the workers to prevent job-hopping is reflected in Indian context as well. On the other hand, in US affiliates where multi-skilling has been encouraged to imbibe flexibility the turnover rates are noticed to be higher. The non-transferability of the famed management techniques of Japanese firms is underscored through our case studies. This is especially ironic as the US firms seem to have adapted these techniques and are using it successfully in the Indian context. The US affiliates show a combination of the known Japanese Management Techniques2, with policies of US nature like promotion according to capability rather than experience, willingness to associate with ex-workers in the capacity of suppliers etc.

2 JMT adopted by US affiliates include bottom to top approach, JIT inventory management, ancillarisation and vendor development, flexibility in production, multi skilling through job rotation 


\section{Backward Linkages Through Networking And Vendor Development}

Linkages developed by MNCs with local suppliers of parts, components and services also form a very important means by which the host economy is expected to benefit on a larger scale. This is because such backward linkages "..generally involve greater interaction than normal market relations between anonymous buyers and sellers.." (Lall, 1980). Increased backward linkages as measured by the local content of manufacturing operations involve transfer of know-how to and growth of local supplying industry. The level of indigenisation, or the ability to put the imported technology to use with the help of locally available resources, is a basic measurement of technology assimilation.

However, the nature and extend of this spillover benefits depend on various other aspects of the FDI firm. The level of integration of production, the extent of indigenisation of inputs used for production, the inventory policy, the mode of entry3, company policy towards vendor development, etc. are some of these.

A tightly integrated vertical production relationship between the parent and the affiliate gives little scope for backward as well as forward linkages within the host economy. These activities are usually undertaken within the international production system of the MNC itself at locations found globally suited for the purpose. This strong relationship build up at the home production base is often carried on when the new production site is developed in a host country either by "tied purchases" 4 or with the vendors following the core firm to the new production site5. This is done in order to maintain the confidentiality of proprietary technology. Either way the linkage effect on the host country gets restricted. This may dampen the potential of industrial growth in the host economy induced through the setting up of vendors of inputs. On the other hand, a firm that builds up its supplier network within the economy results in creating backward linkages and host country industrial development.

The role of supplier networking and vendor development gained relevance with the rise of "strategic management" in the 70s as a means of achieving sustainable competitive advantage for a firm to improve profits and performance. It began to be recognised that the source of advantage extends beyond the boundaries of the firm as firms depend to a large extent on the suppliers to provide highly customised inputs that make a large fraction of the value of the final product. With local subcontracting of inputs becoming the norm to ensure cost efficiency through a reduction in the cycle time, inventory and labour cost; vendor development attained key importance. Supply chain management in order to ensure quality, reliability and timely delivery by the vendor is undertaken by the core firm. Cost minimisation of the vendor can be passed on to the core firm through lower price of the input increasing the competitiveness of the product. This however requires perfect co-ordination between the core firm and the vendor in not only determining the level of output requirement but also through financial, technical and organisational assistance.

Supplier networking relationship can be of three types:

a) Arm's length relationship where in the firm buys inputs from outside using a number of short term suppliers and shops for the best price each time it requires an input

b) Partnership or alliance wherein the firm buys from a small number of suppliers and builds long-term, cooperative relationships with those few suppliers

c) Business networking wherein the suppliers and the firm are in some way linked by way of ownership

The Japanese were the earliest to comprehend that the productivity gains in the production network or value chain are possible when companies are willing to collaborate by sharing resources, knowledge and assets (Dyer and

\footnotetext{
${ }^{3}$ As seen in the previous section a stand-alone affiliate offers greater scope for local linkages and spillovers. Similarly, FDI entry through brown-field investments are expected to yield greater linkages as the linkages set up since the inception of the firm and before the foreign entry is usually continued even after the foreign entry (UNCTAD 2000).

${ }^{4}$ With lifting of import restrictions import of sub-assemblies and semi-finished goods from foreign suppliers that are put together by Indian vendors has been on the rise (Kher 2001)

${ }^{5}$ UNIDO (1990) indicates that the propensity for suppliers to follow the core firm to new production sites overseas is especially common from Japan.
} 
Ouchi 1993). Supply chain management through ancillarisation is considered a keystone of the Japanese efficiency. The Japanese style supplier relationship (known as 'Keiretsu' in Japanese) involves long-run partnerships based on high levels of trust, with investments in dedicated or relationship assets and, creation of inter-organisational knowledge sharing routines throughout the extended enterprise to lower transaction cost and maximise flexibility and responsiveness. This in fact has been offered as one of the explanation for the competitive edge of Japanese firms during the past 30 years (Clark and Fujimoto 1991). The US firm until recently had not appreciated the virtues of 'virtual integration' of supplier firms and shared an 'arm's length relationship' with suppliers. Under this approach, the firm buys inputs from outside using a number of short-term suppliers for the best price each time it requires an input. This strategy involves higher transaction costs (like administrative and inventory holding cost) associated with managing large number of vendors. Multiple suppliers reduces suppliers' ability to achieve economies of scale.

Although parts and components are still imported by CIL a concerted drive towards indegenisation is on to reduce costs of imports. CIL seems to have a comprehensive vendor-development plan with a higher proportion of its output being out-sourced locally6. This is in order to reduce cost and reap rewards of scale economies. 'Treat suppliers as partners' is the philosophy mooted at CIL. There has been concerted effort to narrow the supply base by cutting down the number of suppliers from over 800 to just over 250 in last two years as part of the cost cutting measures. The General Manager of Sourcing also cited that this enabled better relationship with suppliers as it enabled treating the smaller circle of suppliers as partners. The importance of long term partnership relationship is recognised at CIL and the strategy of depending on large number of arm's length suppliers to encourage competition has been abandoned (Table 7).

The increasing importance given to vendor development is reflected by the changes brought about in the Sourcing department to incorporate two sections; one, dealing with the day to day procurement activities concerning itself only with the delivery aspect of supplier and two, the strategic sourcing section concerned with selection, monitoring and assisting the suppliers. Specialist teams constitute the Supplier Quality Improvement (SQI) Cell, dedicated to provide technical and managerial support for the suppliers. Apart from this, financial assistance is provided to suppliers requiring high initial investment to develop new products as well as in the development of dedicated physical assets. The selection of supplier is done after assessment of its technical, financial and managerial capabilities, which are expected to comply with the QS 9000 requirements. A database of such selected firms is maintained and constantly updated. When any new need arises or replacement of present supplier is required for consistently under-performing, the suitable potential supplier is selected from the database. The gaps in the requirements are identified and the SQI cell collaborates with the supplier in bridging it. The SQI is expected to give thorough support during the probation period after which the input is expected to be zero-defect and can be send directly to the production line without further quality check at the CIL.

Apart from the Annual Conference of CIL suppliers, constant training is provided at CIL for suppliers and in the year 2001, 1000 delegates from various supplier units attended it. In order to introduce the concept of JIT through out the value chain, internet based Supply Chain Management has been launched through which the suppliers are updated on the daily changes in the requirements of CIL. In order to ensure efficient time management, CIL has made a conscious attempt to locate their suppliers as near as possible. As a result, 50 per cent of its suppliers fall within 5 hours road radius, while 35 per cent fall within 10 hours radius and 10 per cent fall within 24 hours road radius. Only the foreign suppliers are situated beyond this road radius.

The suppliers at CIL are divided into three categories: critical parts suppliers, strategic components suppliers and regular suppliers. Critical parts constitute parts on which the engineering drawing specifies Cummins Engineering standard, which are produced by propriety process from sources noted on the drawing. These parts require engineering source approval. Strategic component supplier supplies parts with the following characteristics: a) helps differentiate Cummins product b)high barriers to entry hence difficult to reverse sourcing decision c)few good suppliers. All other suppliers are called Regular suppliers. Suppliers of critical parts are often linked by way of ownership to CIL as it involves proprietary knowledge. Strategic parts suppliers are provided with financial and

\footnotetext{
${ }^{6}$ This is not surprising as CIL has been found to be more stand-alone in nature as described in the section on International Organisation of Production.
} 
other modes of assistance as it is difficult to reverse the sourcing decision of the component. Strong partnership relationship is maintained with regular suppliers as well.

Business network relationships within host country are promoted in such circumstances, which provide cost efficiency, scope for transfer pricing as well as ensure co-ordination in the mutual needs of the concerns. Cummins have set up a number of fully owned subsidiaries as well as JVs that supply OEMs to CIL among other customers.

The network suppliers however, form only a small portion in the list of vendors to $\mathrm{CIL}^{7}$. The local vendors are assisted by way of technology supply, training and quality control measures. There have been 20 instances where ex-employees have set up own production to cater to the component needs of CIL. They have been given encouragement by CIL by supplying not only technical assistance but also financial help.

Table 7: Relationship with suppliers

\begin{tabular}{|l|c|c|c|c|}
\hline & \multicolumn{2}{|c|}{ CIL } & \multicolumn{2}{c|}{ Ceekay } \\
\hline \multirow{3}{*}{ Arm's length suppliers } & In No.s & As percentage & In No.s & As percentage \\
\cline { 2 - 5 } Partner suppliers & 0 & 0.0 & 22 & 78.0 \\
Business network suppliers & 243 & 97.2 & 0 & 0.0 \\
Total & 7 & 2.8 & 3 & 12.0 \\
\hline
\end{tabular}

Ceekay on the other hand exhibits high level of vertical integration with most of its production activities undertaken within its roof through in-house processing of pressing, machining, heat treatment, tool room, diaphragm spring and wire ring. Import from Japan was the major source of components not produced under the roof. Moreover, imports as a proportion of total sales as well as to total raw materials consumed has increased in the 90s since liberalisation (Table 8).

Table 8: Vertical linkage effects

\begin{tabular}{|l|c|c|c|c|}
\hline & \multicolumn{2}{|c|}{$\mathbf{1 9 9 0}$} & \multicolumn{2}{c|}{$\mathbf{1 9 9 8}$} \\
\cline { 2 - 5 } & Ceekay & CIL & Ceekay & 29 \\
Value-added/Value of output & 29 & 23 & & 22 \\
Import of raw materials/Total raw & & & 21 & 0.8 \\
material & 7.3 & 0.8 & 10.55 & 0.048 \\
Import of raw materials/Sales & 4.3 & 0.05 & 3.1 & 0.41 \\
Selling cost/Sales & 4.5 & 0.013 & \\
\hline
\end{tabular}

This is not surprising as a vertically integrated production relationship was seen to exist between Ceekay, its parent and other related companies (see section on International Organisation of Production). Moreover with Exedy (then Daikin) being the technology supplier since the inception of the company, the ancillary restraint accompanying technology supply forced it to resort to imports of components. Ceekay reported having only 25 suppliers within the host country, with 22 of whom Ceekay has an arm's length relationship (Table 7). Three suppliers were found related to Ceekay by way of business networks set up with technical and financial collaboration from Exedy, Japan. These parts were considered to be the most technologically complex requiring collaboration with Exedy for obtaining the technology. As in the case of CIL, suppliers' selection at Ceekay requires rigorous assessment to comply with the QS 9000 rating. Although the relationship with the vendor is based on trust and continuing for a long period, no attempt towards networking is evident. The level of interaction with suppliers was restricted to 6-monthly audits. Apart from a few isolated cases of need-based training, no technical or financial assistance is extended to any supplier. It did, however, provide assistance to its local suppliers by way of sending engineers to provide technical assistance. A four-month forecast of demand is provided to suppliers to ensure supply of components. The concept of JIT has not been implemented at Ceekay fully yet and neither is an

\footnotetext{
${ }^{7}$ Until recently, there were over 600 suppliers to CIL which was brought down to 250 to follow a closer partnership relationship
} with them 
effort being made to pass it on to suppliers. Moreover, Ceekay did not report any concerted effort or policy towards import reduction and indigenisation. It continues to be heavily dependent on imported supplies as inputs. The main reason provided for limited local sourcing was the clauses of technology agreements with the parent firm which necessitated imports, as well as inadequate technological capability of the local suppliers to produce the components. Unlike CIL, Ceekay did not have any instance of employee turned supplier to report. The compartmentalised nature of work and lack of multi-skill training in the work-force partly explains absence of this phenomenon.

The Indian partner (TACO) of TJC and TYA, has four other strategic business groups that provide inputs and services to TJC and TYA one of which assists in the Supply Chain Management function of these two companies. This has resulted in TJC building strong backward linkages despite the lifting of import restriction on inputs8. At TJC almost 82 percent of value of output comprises of raw material and intermediary cost, and less than 2 percent of this is found to be imported. This imports is to meet the insistence of one customer Mercedes Benz who specify that the leather and wiring material to be used for manufacturing seats for their models has to be imported from specified suppliers in order to maintain the quality standards. Apart from this, all other outsourcing is done from within the economy.

TJC takes an active and long-term interest in the development of its 25 suppliers insisting on adopting JIT, zero-defects philosophy. The suppliers are linked to TJC through Enterprise Resource Planning (ERP) to ensure close co-ordination and minimisation of wastes. A special and permanent team of experts has been set up to assist and provide technical support to the suppliers. Of the 25 suppliers, 21 are locally owned Indian firms, two are JVs, one is a multinational and one is a domestic firm with foreign technical collaboration. The foreign firms that supply to TJC include IFB for recliners, and Phillips for foam. Track is supplied by Indo-Japanese JVs. Indian firms mainly supply less technology intensive inputs like nuts, bolts, metal frames etc. The major criterion assessed while choosing a supplier is its capability, cost, quality, supplier's supplier and distance from the production unit. Frequent interaction in the form of discussion, joint reviews etc. are held to sort out problems of all nature. Technical assistance in the form of providing designs, technical reports etc. is undertaken by TJC. TJC helps its suppliers reap economies of scale by helping in the export of components to international markets and also insists that the concept of JIT is followed by suppliers too. TJC also benefits from this through cost reduction of its inputs. 90 per cent of suppliers are located within one and half hour radius of TJC.

The other source of spillover through vertical linkages is when past employees set up own production units and become suppliers to the unit. Even with large rates of labour turnover (11 percent of technical experts left last year) at TJC, this phenomenon was not observed. This is because technically qualified personnel have mainly left to join other better paying firms and also because of the general policy of the Tata group not to keep up or entertain any contact with employees who have chosen to leave the firm.

TYA also generates considerable backward linkages through outsourcing, although not upto the extend of TJC. Eighty percent of the outsourcing is done within the economy while the rest 20 percent of high technology inputs is out-sourced from Japan and Singapore. The decision to outsource is to minimise manpower requirements and reduce cost of production though better inventory management as well as scale economies. The suppliers are chosen on the basis of their ability to meet the quality requirements, cost considerations and timely delivery (known as QCD factor). Although no active vendor development activities are undertaken either in the form of technical or financial assistance, one-monthly forecasts are provided to suppliers. Whenever there is any change in technology the new design is shared with the suppliers to enable them to supply components according to the changed specifications. Spillovers through labour turnover too cannot be said to be significant. The labour turnover rate was recorded at about one percent, with no movement recorded among the technical experts. The non-technical managers did move out for better prospects and financial deals. There has been no case of past employee setting up own production unit either to compete or supply components to TYA.

\footnotetext{
${ }^{8}$ This is contrary to the evidence fund in other country contexts where in a unconstrained environment backward linkages are found to be weak (Hill 1985)
} 
Evidence through our case studies may give subtle support to the argument in literature (Capanelli 1997, Froot 1991, Graham \& Krugman 1990, Murray et al. 1995) that the Japanese affiliates are less willing to establish vertical linkages in the host economy. CIL has undertaken serious supply side management as a matter of priority and indegenisation has been encouraged as a way to cost reduction. For this purpose, CIL has set up network companies to supply inputs as well as sales service. CIL also provides active assistance to other local vendors. TJC also is seen to maintain higher local sourcing with less than 2 per cent of input imports as compared to TYA which imports over 20 per cent of inputs.

\section{CONCLUSION}

This paper looked into the transferability of soft technologies through the medium of FDI to the host developing countries. The results of the case studies conducted in the Indian context reveal that significant intersource country differences exist in the transfer of production organisation and human resource related technology to FDI firms (Table 9). Although Japanese firms are considered the pioneers of many of the organisation and managerial technologies, they are seen less willing to transfer it through FDI in a country outside their own. The US affiliates on the other hand, show a combination of the known Japanese Management Techniques9, with policies of US nature like promotion according to capability rather than experience, willingness to associate with ex-workers in the capacity of suppliers etc. Regarding the supplier chain and vendor development activities, the Japanese firms were found to foster arms-length relationship with Indian supplier firms unlike the US affiliates who seem to have realised the importance of partnership relationship with their local suppliers.

To conclude, the benefits that the host country derives from technology transfer through FDI, depend to a large extend on the behavioral pattern of FDI which varies across source-countries. Clearly, the findings of our study have implications in the designing of policies influencing the entry and operation of foreign direct investment in developing countries.

\footnotetext{
9 JMT adopted by US affiliates include bottom to top approach, JIT inventory management, ancillarisation and vendor development, flexibility in production, multi skilling through job rotation
} 
Table 9: Summary of findings on technology transfer behaviour through case studies

\begin{tabular}{|c|c|c|c|c|}
\hline \multirow{2}{*}{ Characteristic } & \multicolumn{2}{|c|}{ US Firms } & \multicolumn{2}{|c|}{ Japanese Firms } \\
\hline & CIL & TJC & Ceeekay & TYA \\
\hline Entry strategy & $\begin{array}{l}\text { Greenfield JV with } 50 \% \\
\text { of equity- post } \\
\text { liberalisation, converted } \\
\text { to majority owned } \\
\text { subsidiary and equity } \\
\text { raised to } 51 \%\end{array}$ & $\begin{array}{l}\text { Greenfield JV with } 50 \% \\
\text { equity share }\end{array}$ & $\begin{array}{l}\text { Brownfield entry to } \\
\text { form JV after a decade } \\
\text { of technical } \\
\text { collaboration- post } \\
\text { liberalisation continues } \\
\text { as JV although equity } \\
\text { has been hiked from } \\
25 \% \text { to } 31 \%\end{array}$ & $\begin{array}{l}\text { Greenfield JV with } 50 \% \\
\text { equity share }\end{array}$ \\
\hline $\begin{array}{l}\text { Capability } \\
\text { building } \\
\text { through } \\
\text { technology } \\
\text { transfer }\end{array}$ & $\begin{array}{l}\text { Initially transfer of } \\
\text { patented technology, } \\
\text { development of } \\
\text { troubleshooting } \\
\text { capability has } \\
\text { progressed to } \\
\text { technological } \\
\text { independence and } \\
\text { export of designs }\end{array}$ & $\begin{array}{l}\text { Initial complete } \\
\text { dependence on } \\
\text { unrestrained transfer of } \\
\text { patented technology has } \\
\text { progressed to } \\
\text { technology } \\
\text { independence and } \\
\text { export of designs }\end{array}$ & $\begin{array}{l}\text { Complete dependence } \\
\text { on Japanese partner for } \\
\text { technology transfer, } \\
\text { adaptation to Indian } \\
\text { conditions \& } \\
\text { troubleshooting }\end{array}$ & $\begin{array}{l}\text { Dependence on } \\
\text { technology continues. } \\
\text { Transfer of technology } \\
\text { has involved some lags. } \\
\text { No patented technology } \\
\text { transferred }\end{array}$ \\
\hline $\begin{array}{l}\text { Nature of } \\
\text { R\&D }\end{array}$ & $\begin{array}{l}\text { Product development } \\
\text { resulting in patents and } \\
\text { export of technology }\end{array}$ & $\begin{array}{l}\text { Product development } \\
\text { resulting in export of } \\
\text { technology }\end{array}$ & $\begin{array}{l}\text { Minor adaptation and } \\
\text { troubleshooting } \\
\text { activities }\end{array}$ & $\begin{array}{l}\text { R\&D activities of } \\
\text { supplementary nature } \\
\text { involving technology } \\
\text { adaptation to Indian } \\
\text { conditions. }\end{array}$ \\
\hline $\begin{array}{l}\text { Production } \\
\text { Organisation }\end{array}$ & $\begin{array}{l}\text { Flexibility in production } \\
\text { through CNC tools and } \\
\text { horizontal job rotation } \\
\text { to ensure multi-skilling, } \\
\text { JIT inventory } \\
\text { management, quality } \\
\text { circles to ensure zero- } \\
\text { defect, }\end{array}$ & $\begin{array}{l}\text { Dedicated as well as } \\
\text { mixed product lines. } \\
\text { Flexibility need of the } \\
\text { latter ensured by CNC } \\
\text { tools, JIT and multi- } \\
\text { skilling by job rotation }\end{array}$ & $\begin{array}{l}\text { Small batch production, } \\
\text { No horizontal job } \\
\text { rotation, JIT introduced } \\
\text { but not efficient }\end{array}$ & $\begin{array}{l}\text { Single product line with } \\
\text { very little } \\
\text { diversification. } \\
\text { Customer specifications } \\
\text { met through CNC tools } \\
\text { JIT inventory } \\
\text { management \& multi- } \\
\text { skilling }\end{array}$ \\
\hline $\begin{array}{l}\text { Human } \\
\text { Resource } \\
\text { Management }\end{array}$ & $\begin{array}{l}\text { Great emphasis on } \\
\text { technical \& behavioural } \\
\text { training to impart } \\
\text { multiple skills \& team } \\
\text { spirit. Bottom-to-top } \\
\text { approach with } \\
\text { suggestions from } \\
\text { workers rewarded } \\
\text { enabling continuos } \\
\text { innovation. High } \\
\text { turnover rate with ex- } \\
\text { employees maintaining } \\
\text { strong relationship as } \\
\text { suppliers in many cases. }\end{array}$ & $\begin{array}{l}\text { Training imparted on } \\
\text { technical, non-technical } \\
\text { and functional nature to } \\
\text { impart multiple skills. } \\
\text { Bottom to top approach } \\
\text { very efficient. High } \\
\text { turnover rate }\end{array}$ & $\begin{array}{l}\text { No formal training with } \\
\text { strictly job specific skill } \\
\text { imparted on a man-to } \\
\text { man basis. Bottom to } \\
\text { top approach not } \\
\text { implemented in earnest. } \\
\text { Low turnover rate. }\end{array}$ & $\begin{array}{l}\text { Importance to training } \\
\text { and suggestion } \\
\text { encouraged from below. }\end{array}$ \\
\hline $\begin{array}{l}\text { International } \\
\text { Integration in } \\
\text { Organisation } \\
\text { structure }\end{array}$ & $\begin{array}{l}\text { Stand-alone in nature, } \\
\text { with minimum control } \\
\text { by US parent in decision } \\
\text { making, most suppliers } \\
\text { and clientele within } \\
\text { country, minimum } \\
\text { expatriate employed and } \\
\text { technology self-reliance. }\end{array}$ & $\begin{array}{l}\text { Integrated with Indian } \\
\text { partner in acquiring } \\
\text { inputs as well as sale of } \\
\text { output. Expatriate } \\
\text { presence only on Board } \\
\text { of Directors. } \\
\text { Technology self reliance } \\
\text { being built up. }\end{array}$ & $\begin{array}{l}\text { Integrated with Japanese } \\
\text { partner production line, } \\
\text { full dependence for } \\
\text { technology, and inputs } \\
\text { channelled from Japan }\end{array}$ & $\begin{array}{l}\text { Horizontal production } \\
\text { relation with Japanese } \\
\text { partner but high degree } \\
\text { of control exercise } \\
\text { through expatriate } \\
\text { employees at all levels } \\
\text { and through technology } \\
\text { dependence. Inputs and } \\
\text { output sourced partially }\end{array}$ \\
\hline
\end{tabular}




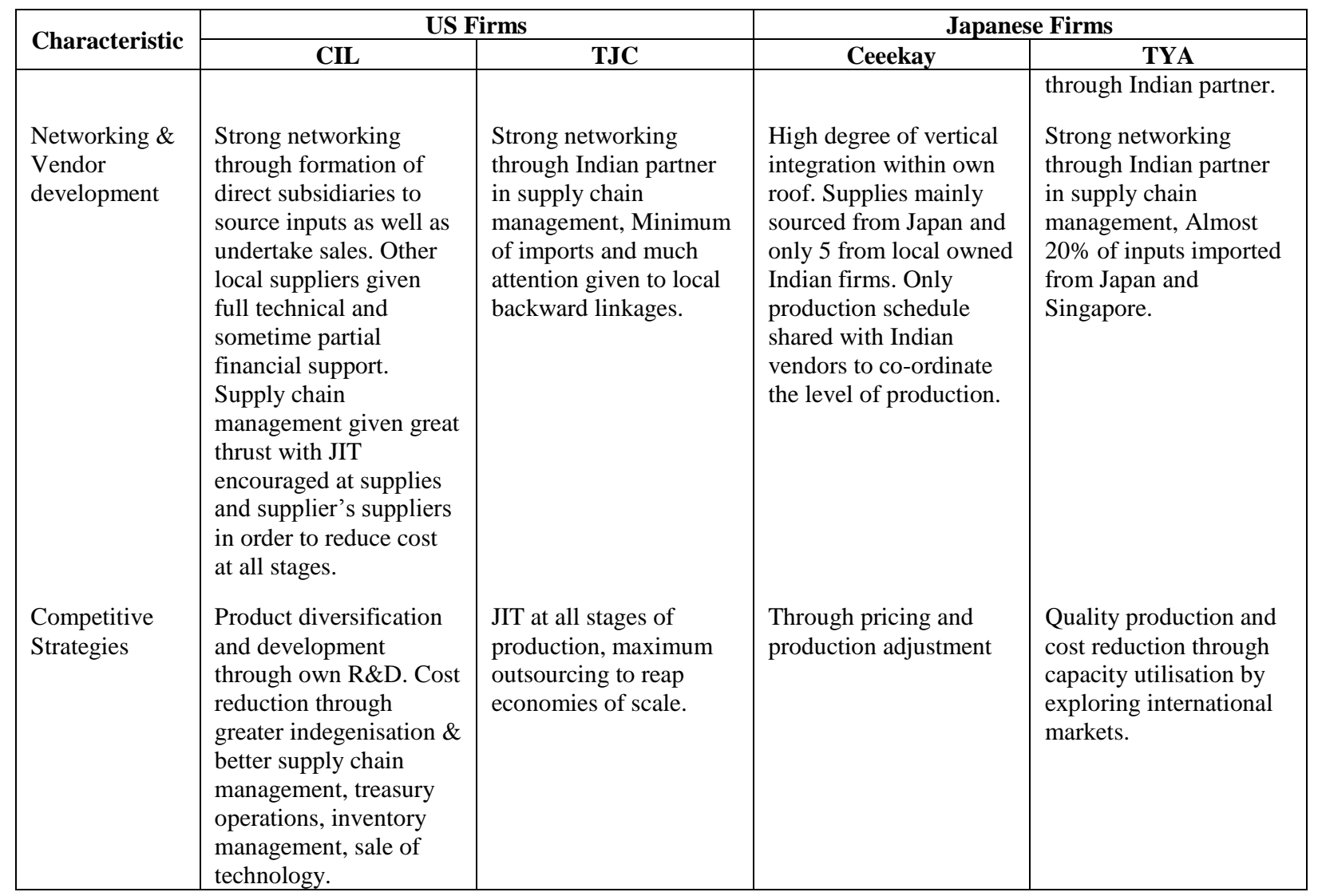

\section{REFERENCES}

1. Borrus, Michael, (1999) 'Left for Dead: Asian Production Networks and the Revival of US Electronics', in Encarnation Dennis J ed. Japanese multinationals in Asia: Regional operations in comparative perspective, New York, OUP.

2. Capannelli, G., (1997) 'Buyer-Supplier relations and technology transfer: Japanese consumer electronics', International Review of Economics and Business, 44(3), 633-662.

3. Cavusgil, S. Tamer, (1985) 'Multinational Corporations and the Management of Technology transfers' in Coskun Samli "Technology Transfer: Geographic, Economic, Cultural and Technical Dimensions" Quorum Books, London.

4. Chen, E. K Y., (1996) 'Transnational Corporations and Technology Transfer to developing countries' in UNCTAD Division on TNCs "Transnational Corporations and World Development" ITBP.

5. Clegg, Jeremy, (1987) Multinational Enterprise and World Competition: A Comparative Study of the USA, Japan, the UK, Sweden and West Germany, Macmillan Press, London.

6. Encarnation, Dennis J., (1999) 'Asia and the global operations of the multinational corporations' in Encarnation Dennis J, ed Japanese multinationals in Asia: Regional operations in comparative perspective, New York, OUP.

7. Erramilli, M., (1996) 'Nationality and subsidiary ownership patterns in Multinational Corporations' Journal of International Business Studies, 26, pp. 225-48.

8. Froot, K.A., (1991) 'Japanese Foreign Direct Investment', Working paper no. 3737, Cambridge MA NBER.

9. Graham, E. M. and Krugman P., (1990) Foreign Direct Investment in the United States, Institute for International Economics, Washington D C.

10. Hill, Hal, (1985) 'Subcontracting, technological diffusion and the Development of Small enterprise in Philippine manufacturing', Journal of Developing Areas, 19, pp245-261.

11. Hoffman Kurt and Raphael Kaplinsky (1988) "Driving Force: The global restructuring of Technology, labour and investment in the Automobile and components Industries" Westview Press UNCTC study. 
12. Institute of Developing Economies, (1994) The Role of Japanese Direct Investment in Developing Countries: India, Indonesia, Taiwan, (Tokyo), March.

13. Kaplinsky, Raphael, (1995) 'Techniques and system: The spread of Japanese management techniques to developing countries', World Development, 23(1), pp. 57-71.

14. Kojima, K., (1978) Direct Foreign Investment, Croomhelm, London.

15. Kumar, Nagesh and N.S. Siddharthan, (1997) Technology, market Structure and Internationalisation: Issues and Policies for Developing Countries. London and New York: Routledge.

16. Kumar, Nagesh, (2002) Globalisation and the Quality of Foreign Direct Investment, Oxford University Press, New Delhi.

17. Lall, Sanjaya, 1980. "Developing countries as exporters of industrial technology," Research Policy, Elsevier, vol. 9(1), pages 24-52, January.

18. Lan, Ping, (1996) Technology Transfer to China through Foreign Direct Investment, Avebury, England.

19. Mody, Asoka and Srinivasan Krishnan, (1998) 'Japanese and US firms as foreign investors: Do they march to the same tune?', Canadian Journal of Economics, 31(4) October pp. 778-99.

20. Morgan, Glenn, (2001) 'The Multinational Firm: Organizing Across Institutional and National Divides', in Morgan Glenn, Peer Hull Kristensen and Richard Whitley (ed), The Multinational Firm: Organizing Across Institutional and National Divides, OUP, New York.

21. Murray, J. Y., Wildt R. and Kotabe M., (1995) 'Global Sourcing Strategies of US affiliates of Foreign Multinationals', Management International Review, 35(4), pp. 307-324.

22. Nayyar, Deepak, (1983) 'International Relocation of Production and Industrialisation in LDCs', Economic and Political Weekly, vol. 18, pp. 13-26.

23. Negandhi, Anant and B. Rajaram Baliga, (1979) Quest for Survival and Growth: A comparative study of American, European and Japanese Multinationals, Praeger Publishers, New York.

24. Orr, D., (1973) 'Foreign control and Foreign Penetration in the Canadian Manufacturing Industries', unpublished paper, Vancouver, Canada: University of British Columbia. As referred in Clegg Jeremy(1987), Multinational Enterprise and World Competition: A Comparative Study of the USA, Japan, the UK, Sweden and West Germany, Macmillan Press, London.

25. Ozawa, T., (1979a) 'International Investment and Industrial Structure: New Theoretical Implications from the Japanese Experience', Oxford Economic Papers, 31 (March), pp. 72-92.

26. Ravenhill (1999) 'Japanese and U.S. Subsidiaries in East Asia: Host-Economy Effects', in Encarnation Dennis J (1999) ed Japanese multinationals in Asia: Regional operations in comparative perspective, New York, OUP.

27. Samuelson, H. F., (1977) 'Foreign Direct Investment in Sweden-An Econometric Analysis', Stockholm: Industriens Utredningsinstitut as referred in Clegg Jeremy(1987), Multinational Enterprise and World Competition: A Comparative Study of the USA, Japan, the UK, Sweden and West Germany, Macmillan Press, London.

28. Sedgewick, Mitchell, (1995) 'Does Japanese Management Travel in Asia?: Managerial Technology Transfers at Japanese Multinationals in Thailand' University of Cambridge, Draft for the conference volume "Does Ownership matter?: Japanese Multinationals in Asia."

29. Sidharthan, N. S., (1998) 'European and Japanese affiliates in India: Differences in conduct and performance', working paper no. E/198/98, Institute of Economic Growth, New Delhi.

30. Stewart, T., Charles Jr., and Yasumitsu Nehei, (1987) Technology Transfer and Human Factors, Lexington Books, Massachusetts/Toronto.

31. UNCTAD, (1993) "Small and Medium Sized Transnational Corporations: Role Impact and Policy Implications" United Nations New York.

32. Urata, Shujiro, (1995) 'Japanese foreign Direct Investment and Technology Transfer in Asia' presented at the Conference on Does Ownership matter: Japanese Multinationals in Asia, at MIT Sep. 20-21.

33. Yamashita, Shoichi, (1990) Transfer of Japanese Technology and Management to the Asean Countries, University of Tokyo Press.

34. Yoshihara Kunio (1978) Japanese Investment in Southeast Asia, The Centre for South east Asian studies, Kyoto University, Kyoto, Japan. 